\title{
International Journal of

\section{Incidentally Found Thyroid Metastases in Head and Neck Squamous Cell Carcinoma - How to Manage It?}

\author{
Gama $R^{*}$ (D) Oliveira $P$, Teixeira $M$, Castro $F$ and Condé $A$ \\ Department of Otorhinolaryngology and Head and Neck Surgery, Vila Nova de Gaia/Espinho Hospital \\ Center, Portugal
}

*Corresponding author: Rita Gama, Serviço de Otorrinolaringologia e Cirurgia de Cabeça e Pescoço do Centro Hospitalar de Vila Nova de Gaia e Espinho E.P.E, Rua Conceição Fernandes 1079, 4434-502 Vila Nova de Gaia, Portugal, Tel: 227865-100, Fax: 227-830-209

\begin{abstract}
Objectives: The authors aim to review the available literature regarding incidentally found thyroid carcinoma during lymph node dissection for primary head and neck squamous cell carcinoma (SCC), in order to potentially support clinical decision about management of this unexpected entity.

Methods: 2 clinical cases are described and a systematic review of the relevant literature on the subject is performed based on Pubmed $囚$ database.

Results: We reviewed a total of 102 cases. The primary SCCs sites were larynx, oral cavity, and pharynx. Thyroidectomy was performed in 79 cases and thyroid carcinoma was found on histology in 40 cases, mainly papillary subtype.

Conclusion: The scenario of thyroid carcinoma incidentally found in head and neck SCC is very unusual. The decision between surgical and conservative management should be made on an individualized basis, considering the biological properties of the thyroid neoplasm itself and, mainly, the prognosis of the primary head and neck disease.
\end{abstract}

\section{Keywords}

Head and neck neoplasms, Carcinoma, Thyroid carcinoma, Lymphatic metastasis

\section{Introduction}

The occurrence of multiple synchronous malignant tumours represents an important medical issue. It affects about till $20 \%$ of the head and neck squamous cells carcinoma (SCC) patients, and the evidence supports that these second primaries occurring in SCC patients share similar properties, like biologic behaviour, epidemiology and etiologic factors [1]. Thus these tumours usually arise in men, are associated with smoking and alcoholic habits, affect mainly the upper aerodigestive tract, most commonly the head and neck, lungs and oesophagus, and are usually SCC [2].

On the other hand, thyroid carcinoma affects primarily the women, it is usually well-differentiated and is manifested through the emergence of a neck mass or compressive symptoms. Besides, its aetiology and biological behaviour is quite different from that of head and neck SCC.

Therefore, thyroid carcinoma occurring as a second primary tumour in head and neck SCC patients is very unusual. However, it can be discovered incidentally in the histopathological analysis of neck dissection specimen after surgical treatment of these patients $[3,4]$.

Papillary carcinoma is the most frequent thyroid tumour occurring incidentally with head and neck SCC. This association is very difficult to suspect, as it usually is asymptomatic and radiologically non evident, thus representing a serious and problematic challenge in terms of management [5]. Its occurrence is rare and little has been published on this subject. Besides, the rarely published cases describe greatly different management approaches.

To the best of our knowledge, 100 cases of synchronous thyroid carcinoma in head and neck SCC patients were reported. From those, only a few describe

Citation: Gama R, Oliveira P, Teixeira M, Castro F, Condé A (2021) Incidentally Found Thyroid Metastases in Head and Neck Squamous Cell Carcinoma - How to Manage It?. Int J Oncol Res 4:031. doi. org/10.23937/2643-4563/1710031

Accepted: September 08, 2021: Published: September 10, 2021

Copyright: (C) 2021 Gama R, et al. This is an open-access article distributed under the terms of the Creative Commons Attribution License, which permits unrestricted use, distribution, and reproduction in any medium, provided the original author and source are credited. 
Table 1: Patient characteristics.

\begin{tabular}{|l|l|l|l|l|l|l|l|l|}
\hline Patient & Age & Gender & cTNM & SCC Site & SCC in LN & PTC in LN & Thyroidectomy & Follow-up \\
\hline 1 & 60 & Male & T4NOM0 & Supraglottis & 0 & 1 (left) & Right lobe PTC & FOD \\
\hline 2 & 52 & Female & T3NOMO & Glottis & 0 & 1 (right) & Bilateral PTC & FOD \\
\hline
\end{tabular}

FOD: Free Of Disease; LN: Lymph Nodes; PTC: Papillary Thyroid Carcinoma

incidentally found thyroid carcinoma during lymph node dissection for primary head and neck SCC.

In this study, 2 cases of head and neck SCC associated with papillary thyroid carcinoma metastases in the dissected cervical lymph nodes are reported, and a review of the relevant literature is performed.

Our aim was to clarify and support clinical decision about management and surgical treatment of unexpected thyroid carcinoma found incidentally during lymph node dissection for primary head and neck SCC [5].

\section{Methods}

In this study, 2 cases of papillary thyroid carcinoma metastases incidentally found in the dissected cervical lymph nodes are described. Additionally, a systematic review of the relevant literature is demonstrated and discussed, based on a research undertaken in the Pubmed $^{\oplus}$ database, which included articles published till January 2020, found through the terms "thyroid carcinoma", "thyroid metastasis", "neck dissection and thyroid disease", "neck dissection findings", "incidentally found thyroid carcinoma". Articles in English and Portuguese were considered $(n=111)$. Clinical-case reports and systematic reviews were included. Exclusion criteria included non-human studies, autopsy-based studies, and reports that did not describe incidentally found metastasis of thyroid carcinoma in head and neck SCC. After abstract processing, 16 articles were included.

\section{Results}

\section{Case reports}

Case 1: A 60-year-old male patient was diagnosed with a left supraglottic SCC with extension to glottic and subglottic regions, staged as cT4NOMO. He was subjected to total laryngectomy with bilateral functional neck dissection. On histological analysis no metastatic SCC lymph nodes were detected; however, micro metastases of papillary thyroid carcinoma were found in one left lymph node (level III). Computed tomography (CT) scan and Magnetic Resonance Imaging (MRI) were negative for thyroid cancer. 20 days after the primary surgery, a total thyroidectomy was performed, and the resected thyroid tissue revealed a right papillary carcinoma with $15 \mathrm{~mm}$, staged as pT1bN1a. No nodules were observed on the left thyroid lobe. The patient underwent adjuvant neck radiotherapy, and is free of disease after 2 years of follow-up.
Case 2: A 52-year-old female patient was diagnosed with a left glottic SCC, staged as CT3NOMO. She undergone total laryngectomy associated with functional bilateral neck lymph node dissection. The histologic analysis revealed no metastatic nodes from de SCC but one of the right side nodes (level IV) was invaded with papillary thyroid metastatic carcinoma. She underwent total thyroidectomy 15 days after the first surgery; the histologic examination revealed papillary carcinoma on the right lobe with $14 \mathrm{~mm}$, as well as multiple papillary microcarcinoma on the left lobe. The patient is nowadays free of disease after 5 years of follow-up. The patient characteristics are described in Table 1.

\section{Literature review}

We include in this review 16 articles on thyroid carcinoma found on neck lymph node dissection performed for head and neck SCC, with a total of 102 cases. The primary SCCs were located more frequently in the larynx ( $n=39$ ) and oral cavity $(n=27)$, followed by pharynx $(n=13)$ (Table 2$)$. Thyroidectomy was performed in 79 cases and, from those, thyroid carcinoma was found on histological examination in 40 cases: 25 were papillary, 2 were follicular and 13 cases revealed mixed features. The histological type was not described in 16 cases.

\section{Discussion}

Squamous cell carcinoma is the most common malignancy found in the head and neck. The occurrence of a synchronous neoplasm, in the form of a papillary thyroid carcinoma is an extremely rare phenomenon that has been rarely described in the literature [6].

It is known that incidentally and non-symptomatic thyroid carcinoma is not uncommon; autopsy studies reveal a prevalence rate of thyroid malignancy of about $6 \%$ in the general population $[7,8]$. Besides, an occult thyroid carcinoma incidentally found during image or surgery for other indications is not uncommon and is usually considered of minor significance. What is very different is to incidentally find a metastatic thyroid neoplasm during surgery for head and neck SCC, and it raises a number of important and controversial issues: on one hand, to find a metastatic thyroid lesion in a cervical lymph node is generally pursued more aggressively because these are advanced staged lesions; on the other hand, a SCC is, itself, a much more aggressive disease than the majority of thyroid neoplasms, usually with a worst prognosis, in such a way that the patient's outcome is more probably determined by the SCC, 
Table 2: Thyroid carcinoma incidentally found during surgery for head and neck SCC.

\begin{tabular}{|c|c|c|c|c|c|c|}
\hline & Year & $\begin{array}{l}\text { No. of } \\
\text { cases }\end{array}$ & $\begin{array}{l}\text { Head and } \\
\text { Neck SCC }\end{array}$ & $\begin{array}{l}\text { Number of } \\
\text { thyroidectomies }\end{array}$ & $\begin{array}{l}\text { Carcinoma/number of } \\
\text { thyroidectomies }\end{array}$ & $\begin{array}{l}\text { Histology of thyroid } \\
\text { carcinoma }\end{array}$ \\
\hline Clark, et al. [11] & 1966 & 16 & $\begin{array}{l}\text { Oral cavity } \\
6 ; \text { larynx } 8 ; \\
\text { pharynx } 2\end{array}$ & 13 & $11 / 13$ & $\begin{array}{l}\text { Papillary } 2 \\
\text { Mixed } 9\end{array}$ \\
\hline Butler, et al. [10] & 1967 & 10 & $\begin{array}{l}\text { Oral cavity } \\
4 \text {; larynx } 5 \\
\text { pharynx } 1\end{array}$ & 6 & $4 / 6$ & Mixed 4 \\
\hline $\begin{array}{l}\text { Pacheco-Ojeda, et } \\
\text { al. [6] }\end{array}$ & 1991 & 10 & $\begin{array}{l}\text { Oral cavity } \\
2 \text {; larynx } 4 \text {; } \\
\text { pharynx } 4\end{array}$ & 9 & $\mathrm{nd} / 9$ & nd \\
\hline $\begin{array}{l}\text { Vassilopoulou- } \\
\text { Sellin, et al. [9] }\end{array}$ & 1992 & 8 & Oral cavity 4 & 4 & $2 / 4$ & Follicular 2 \\
\hline Pitman, et al. [2] & 1996 & 7 & $\begin{array}{l}\text { Oral cavity } \\
2 ; \text { larynx } 4 ; \\
\text { pharynx } 1\end{array}$ & 7 & $\mathrm{nd} / 7$ & Papillary 7 \\
\hline $\begin{array}{l}\text { Lopez-Escamez, et } \\
\text { al. [13] }\end{array}$ & 1999 & 1 & Larynx 1 & 1 & $0 / 1$ & 0 \\
\hline $\begin{array}{l}\text { Fliegelman, et al. } \\
\text { [18] }\end{array}$ & 2001 & 4 & Oral cavity 4 & 4 & $2 / 4$ & Papillary 2 \\
\hline Coskun, et al. [1] & 2001 & 3 & Larynx 3 & 2 & $1 / 2$ & Papillary 1 \\
\hline Resta, et al. [16] & 2003 & 8 & $\begin{array}{l}\text { Oral cavity } 1 ; \\
\text { larynx } 7\end{array}$ & 4 & $1 / 4$ & Papillary 1 \\
\hline $\begin{array}{l}\text { Ansari-Lari, et al. } \\
{[17]}\end{array}$ & 2003 & 10 & Head and neck & 6 & $5 / 6$ & Papillary 5 \\
\hline Léon, et al. [3] & 2005 & 5 & $\begin{array}{l}\text { Larynx 3; } \\
\text { pharynx } 2\end{array}$ & 3 & $1 / 3$ & Papillary 1 \\
\hline Yamamoto, et al. [5] & 2006 & 3 & Oral cavity 3 & 3 & $0 / 3$ & 0 \\
\hline Guzzo, et al. [4] & 2006 & 8 & Head and neck & 8 & $7 / 8$ & nd \\
\hline Favero, et al. [12] & 2007 & 2 & Pharynx 2 & 2 & $2 / 2$ & Papillary 2 \\
\hline Dokuzlar, et al. [19] & 2009 & 3 & Larynx 3 & 3 & $1 / 3$ & Papillary 1 \\
\hline $\begin{array}{l}\text { Vamanshankar, et } \\
\text { al. [20] }\end{array}$ & 2016 & 2 & $\begin{array}{l}\text { Oral cavity } 1 ; \\
\text { pharynx } 1\end{array}$ & 2 & $1 / 2$ & Papillary 1 \\
\hline Present report & 2019 & 2 & Larynx 2 & 2 & $2 / 2$ & Papillary 2 \\
\hline Total & & 102 & $\begin{array}{l}\text { Oral cavity } 27 ; \\
\text { Larynx } 39 ; \\
\text { Pharynx } 13\end{array}$ & 79 & $40 / 79$ & $\begin{array}{l}\text { Papillary } 25 \\
\text { Follicular } 2 \\
\text { Mixed } 13 \\
\text { nd } 16\end{array}$ \\
\hline
\end{tabular}

nd: not described

rather than the by the management of the thyroid disease [9].

\section{About the origin}

There seems to be a controversy on the origin of lymph nodes with thyroid lesions. The presence of thyroid tissue in cervical lymph nodes was reason for discussion for decades $[2,10,11]$. The reason for the discussion is around the subject of whether thyroid tissue on neck lymph nodes would represent thyroid carcinoma metastasis or benign thyroid tumor. Haller (1779) hypothesized, for the first time, the presence of thyroid tissue in cervical lymph node as reflecting the embryological displacement of the lateral thyroid anlage $[10,12]$. That tissue was later called "aberrant lateral thyroid" and had the tendency to undergo papillary changes in response to physiological stimuli. This theory was abandoned due to the observations reported by Butler and Clark $[10,11]$, who demonstrated that the presence of thyroid tissue in the cervical lymph nodes would represent, in almost all cases, primary thyroid tumor metastasis, much more than aberrant lateral thyroid tumor; these authors concluded that it could not be said that the thyroid would be free of cancer without an exhaustive microscopic study due to the fact that foci of both papillary and follicular carcinoma may be impalpable, even at operation, and may not be demonstrable by scintigrams, in routine microscopic studies or even in section examination of the entire gland. 
Pitman defended that when it is found incidentally in the neck, the hidden focus on the thyroid may be less than $1.5 \mathrm{~cm}$ and that the incidence of occult papillary carcinoma could achieve 5 to $20 \%$ of the cases [2]; many studies demonstrated that even the smallest thyroid nodules has the potential to produce lymph node metastasis [13-15], showing that any occult papillary carcinoma, regardless of the small size, has a significant cervical lymph node metastatic potential. So, the normal clinical appearance of the thyroid gland does not exclude, at all, the possibility of a primary thyroid carcinoma.

\section{About the treatment}

There is still no consensus about how to deal with this rare finding, Treatment options are many, and include total thyroidectomy, thyroid lobectomy, the administration of radioactive iodine, and/or the use of external beam radiation. These options should be weighed against the option of conservative treatment close clinical surveillance. May the options be discussed so that it could make easier the management of these patients in the clinical setting?

Regarding the treatment of this extremely rare finding, some authors defend a conservative approach with surveillance as the most appropriate management for all cases of incidentally found metastasis of thyroid carcinoma in head and neck SCC patients. They concluded that the patient outcome is predominantly determined by the primary head and neck malignancy, which usually constitutes a far worse prognosis disease than the thyroid carcinoma, so that thyroid disease does not require surgical treatment, and clinical observation is adequate [9]. Besides, many studies revealed a longterm follow-up free of any clinically evident thyroid disease in patients that did not receive any treatment for incidentally found thyroid cancer $[4,9,10,16,17]$. Of course some factors influence a change in this approach, such as the emergence of a thyroid nodule, compressive symptoms or evidence of invasive disease.

On the other hand, authors like Pitman, Clark and Butler defend that total thyroidectomy should be performed in all cases: first, because these patients with head and neck SCC fall in an age group that corresponds to an intermediate risk group of thyroid carcinoma. Second, even in cases in which a normal thyroid gland is seen, small foci of microcarcinoma cannot be totally excluded, what, in a scenario of metastatic implants of papillary carcinoma, could represent a disastrous situation. Third, it is known that early diagnosed papillary thyroid carcinoma (the most common feature found in this review) is probably a curable entity and that later in the evolution of the disease there is a risk, although small, of transformation to higher grade cancer, with an inherent worst prognosis. Thus, some of the patients with head and neck SCC that have good prognosis don't have to live with the knowledge and concern of an untreated thyroid cancer.

Considering that each patient has its own clinical context, like age, comorbidities, location and stage of $\mathrm{SCC}$, and treatment required for the SCC, the approach of the thyroid malignancy must be conducted on an individualized basis.

The author's perspective is in accordance with conservative approaches and surveillance in cases of inadequacy for surgery (for example, when the prognosis of the primary head and neck SCC is bad so that determines not invasive measures), if patient refuses the surgical treatment or if external beam radiation therapy is needed for head and neck carcinoma treatment, because this may be adequate therapy for thyroid neoplasm; in all other cases, and considering that we talk about a metastasizing type of thyroid carcinoma with an potentially unpredictable behaviour, we advocate the surgical resection in all of them.

In conclusion, the aim of the management should be consonant with the relative threat to life of the thyroid carcinoma compared with the predicted prognosis of the head and neck SCC for which the patient was primarily referred for treatment.

\section{Conclusions}

The scenario of thyroid carcinoma incidentally found in the neck treated for a head and neck SCC is very unusual. Therefore, the available literature about it is scarse and reveals divergent conclusions. The decision between surgical treatment and conservative observational management should be made on an individualized basis, taking into account multiple variants, including biological properties of the thyroid neoplasm itself, patient's comorbidities and choice and, mainly, the prognosis of the primary head and neck disease. Given the potentially metastasizing nature of thyroid carcinoma and its unpredictable behaviour, the authors advocate the surgical resection in all of them.

\section{Acknowledgements}

No acknowledgements to be done.

\section{Declarations}

\section{Funding}

The authors have no conflict of interests to declare or any founding source to describe.

\section{Conflict of interests}

The authors have no conflict of interests to declare.

\section{Consent for publication}

All the authors consent the submission and publication of this paper. 


\section{Bullet Point Summary}

1. The scenario of thyroid carcinoma incidentally found in the neck treated for a head and neck SCC is very unusual.

2. The presence of thyroid tissue in cervical lymph nodes, previously considered as aberrant embryonic thyroid tissue, should be considered as an expression of metastatic thyroid cancer, even in the absence of thyroid lesions.

3. Treatment options are many, and include total thyroidectomy, thyroid lobectomy, the administration of radioactive iodine, and/ or the use of external beam radiation. These options should be weighed against the option of conservative treatment - close clinical surveillance. On our both cases presented, we decided to perform total thyroidectomy.

4. There is still no consensus about how to deal with this rare finding.

5. The approach of the thyroid malignancy must be conducted on an individualized basis.

\section{References}

1. Coskun H, Erisen L, Tolunay S, Basut O, Onart S, et al (2002) Incidental Association of Thyroid Carcinoma and Squamous Cell Carcinoma of Head and Neck. Am J Otolaryngol 23: 228-232.

2. Pitman KT, Johnson JT, Myers EN (1996) Papillary Thyroid Carcinoma Associated With Squamous Cell Carcinoma of the Head and Neck: Significance and Treatment. Am J Otolaryngol 17: 190-196.

3. León X, Sancho FJ, García J, Sañudo JR, Orús C, et al. (2005) Incidence and Significance of Clinically Unsuspected Thyroid Tissue in Lymph Nodes Found During Neck Dissection in Head and Neck Carcinoma Patients. Laryngoscope 115: 470-474.

4. Guzzo M, Quattrone P, Seregni E, Bianchi R, Mattavelli F (2007) Thyroid carcinoma associated with squamous cell carcinoma of the head and neck: which policy? Head Neck 29: 33-37.

5. Yamamoto T, Tatemoto Y, Hibi Y, Ohno A, Osaki T (2008) Thyroid Carcinomas Found Incidentallyin the Cervical Lymph Nodes: Do They Arise From Heterotopic Thyroid Tissues ? J Oral Maxillofac Surg 66: 2566-2576.

6. Pacheco-Ojeda L, Micheau C, Luboinski B, Richard J, Travagli JP, et al. (1991) Squamous Cell Carcinoma of the Upper Aerodigestive Tract Associated With Well- Differentiated Carcinoma of the Thyroid Gland. Laryngoscope 101: 421-424.

7. Sobrinho-Simoes M, Sambade MC, Gonçalves V (1979) Latent thyroid carcinoma at autopsy A Study from Oporto, Portugal. Cancer 43: 1702-1706.
8. Bisi H, Fernandes VS, de Camargo RY, Koch L, Abdo $\mathrm{AH}$, et al. (1989) The Prevalence of Unsuspected Thyroid Pathology in 300 Sequential Autopsies, With Special Reference to the Incidental Carcinoma. Cancer 64: 18881893.

9. Vassilopoulou-Sellin R, Weber RS (1992) Metastatic thyroid cancer as an incidental finding during neck dissection: significance and management. Head Neck 14: 459-463.

10. Butler JJ, Tulinius H, Ibanez ML, Ballantyne AJ, Clark RL (1967) Significance of thyroid tissue in lymph nodes associated with carcinoma of the head, neck or lung. Cancer 20: 103-112.

11. Clark RL, Hickey RC, Butler JJ, Ibanez ML, Ballantyne AJ (1966) Thyroid Cancer Discovered Incidentally during Treatment for an Unrelated Head and Neck Cancer: Review of 16 Cases. Ann Surg 163: 665-671.

12. Favero E, Pasquoto M, Luiza M, Andrade JA, Mello MC, et al. (2007) Achado incidental de carcinoma de papilífero de tireóide em esvaziamentos cervicais. Rev Bras Cir Cabeça Pescoço 36: 6-8.

13. López-Escámez JA, López-Nevot A, Moreno-García MI, Gámiz MJ, Salinero J (1999) Cervical Metastasis of Occult Papillary Thyroid Carcinoma Associated with Epidermoid Carcinoma of the Larynx. ORL J Otorhinolaryngol Relat Spec 61: 224-226.

14. Martinez-Tello FJ, Martinez-Cabruja R, Fernandez-Martin J, Lasso-Oria C, Ballestin-Carcavilla C (1993) Occult carcinoma of the thyroid. A systemic autopsy study from Spain of two series performed with two different methods. Cancer 71: 4022-4029.

15. Sampson RJ, Oka K, Key CHR BC, S lijima (1970) Metastases from occult thyroid carcinoma: An autopsy study from Hiroshima and Nagasaki, Japan. Cancer 25: 803-811.

16. Resta L, Piscitelli D, Grazia M, Nicola VD, Fiorella ML, et al. (2004) Incidental metastases of well-differentiated thyroid carcinoma in lymph nodes of patients with squamous cell head and neck cancer: Eight cases with a review of the literature. Eur Arch Otorhinolaryngol 261: 473-478.

17. Ansari-lari MA, Westra WH (2003) The prevalence and significance of clinically unsuspected neoplasms in cervical lymph nodes. Head Neck 25: 841-847.

18. Fliegelman LJ, Genden EM, Brandwein M, Mechanick J, Urken ML (2001) Significance and management of thyroid lesions in lymph nodes as an incidental finding during neck dissection. Head Neck 23: 885-891.

19. Dokuzlar U, Erisen LM, Kasapoglu F, Coskun H, Basut O, et al. (2009) Unexpected findings in the neck dissection specimens for primary head and neck squamous cell carcinoma Unexpected findings in the neck dissection specimens for primary head and neck squamous cell carcinoma. Kulak Burun Bogaz Ihtis Derg 19: 9-15.

20. Vamanshankar H, Ganesan S, Alexander A (2017) Papillary carcinoma thyroid coexisting with squamous cell carcinoma: series of two cases. Egypt J Otolaryngol 33: 549-553. 